\title{
Immunomodulation of epithelium
}

\author{
MARY H PERDUE PhD
}

\begin{abstract}
MH Perdue. Immunomodulation of epithelium. Can J Gastroenterol 1996;10(4):243-248. Many studies have provided evidence that the immune system is a key regulatory system of intestinal function. The interaction of immune cells with the gut epithelium plays an important role in host defence, acting to eliminate pathogens, antigens and other noxious material from the lumen of the gastrointestinal tract. During inflammatory conditions of the gut, the mucosa becomes packed with immune cells in close proximity to the enterocytes. Mediators released from these cells have profound effects on epithelial functions. The two main functions of the intestinal epithelium are to transport nutrients, ions and water, and to act as a barrier to prevent unimpeded uptake of antigenic material and microbes from the lumen. Both these functions are altered by immune reactions in response to various stimuli. Topics discussed include mast cells and epithelial function; mast cell-nerve interaction; mast cell activation; neutrophils, eosinophils and macrophages; T cells; and prostaglandins and immune cell activation.
\end{abstract}

Key Words: Epithelium, Immunomodulation, Mast cells, Prostaglandins, T cells

\section{Immunomodulation de l'épithélium}

RÉSUMÉ : De nombreuses études ont confirmé que le système immunitaire joue un rôle régulateur clé sur la fonction intestinale. L'interaction des cellules immunitaires et de l'épithélium intestinal joue un rôle important dans la protection de l'hôte, éliminant les organismes pathogènes, les antigènes et autres substances nuisibles de la lumière du tractus digestif. En présence de maladies dues à une inflammation de l'intestin, la muqueuse se trouve envahie par les cellules immunitaires qui se trouvent à proximité des entérocytes. Les médiateurs libérés à partir de ces cellules exercent des effets marqués sur les fonctions épithéliales. Les deux principales fonctions de l'épithélium intestinal sont le transport des éléments nutritifs, des ions et de l'eau et également la protection contre l'absorption indue de matériel antigénique et de microbes à partir de la lumière intestinale. Ces deux fonctions sont altérées par les réactions immunitaires en réponse aux divers stimuli. Les sujets abordés dans cet article sont entre autres les mastocytes et la fonction épithéliale, l'interaction mastocytes-cellules nerveuses, l'activation des mastocytes, les neutrophiles, éosinophiles et macrophages et l'activation de l'immunité cellulaire.
$\mathrm{O}$ ver the past several years, many studies have provided evidence that the immune system is a key regulatory system of intestinal function. 'Immunophysiology' has been coined as a term to describe the control of physiology by immune cells and their chemical mediators. The interaction of immune cells with the gut epithelium plays an important role in host defence, acting to eliminate pathogens, antigens and other noxious material from the lumen of the gastrointestinal tract.

In the intestine, the epithelium is a layer of single cells extending over the mucosal surface and down into the crypts. The main cells in the epithelium are the transporting enterocytes that are joined together at their apical surfaces by tight junctions and are supported beneath the basal lamina by a fibroblast sheath. The lamina propria contains nerves and a large variety of immune cells, including $T$ and $B$ lymphocytes, plasma cells, macrophages, mast cells, eosinophils and neutrophils. These cells can react to an antigenic stimulus either specifically via self-generated receptors or by

Intestinal Disease Research Program, Department of Pathology, McMaster University, Hamilton, Ontario

Correspondence: Dr Mary Perdue, McMaster University, HSC-3N5C, 1200 Main Street West, Hamilton, Ontario L8N 325. Telephone 905-525-9140 ext 22585, fax 905-522-3454, e-mail perdue@fhs.mcmaster.ca

This paper was presented at the Basic Research and Clinical Implications in IBD meeting, April 6 to 9, 1994, held in Victoria, British Columbia. This paper has also been published in Sutherland LR, et al, eds. Inflammatory Bowel Disease: Basic Research, Clinical Implications and Trends in Therapy. Boston, Dordrecht and London: Kluwer Academic Publishers, 1994 


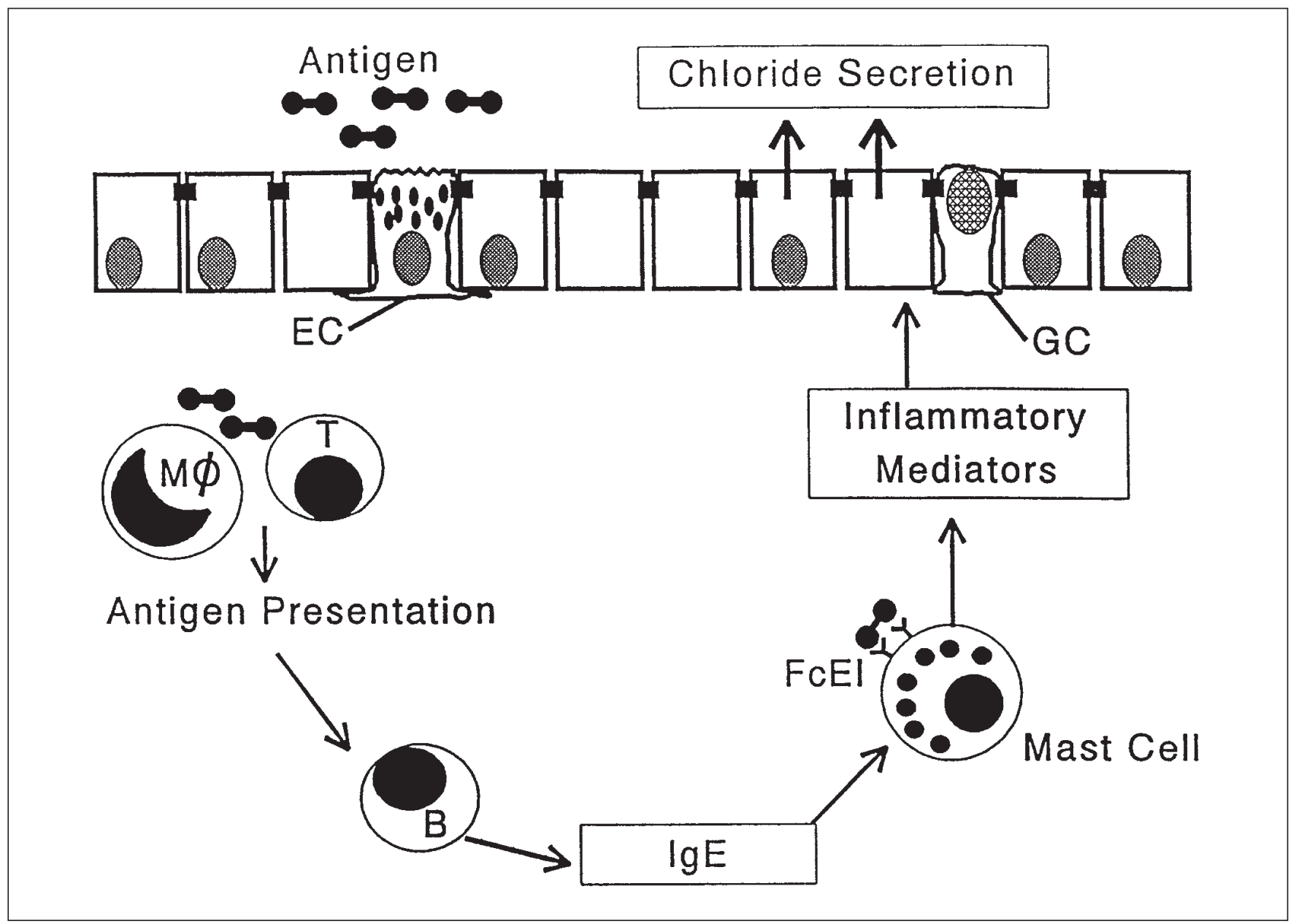

Figure 1) Traditional schema for intestinal hypersensitivity reactions. Primary exposure to antigen results in the formation of immunoglobulin (Ig) E antibodies by B cells (B). Secondary exposure to antigen results in cross-linking of IgE bound to the mast cell surface and subsequent release of mediators that act on epithelial cells (EC) to stimulate secretion of chloride ions. FcEI High affinity IgE receptor; GC Goblet cells; M $\Phi$ Macrophages; T T cells

virtue of their ability to bind antibodies, or nonspecifically to bacterial products such as endotoxin or other activators. Antigenic simulation results in expansion of resident immune cell populations. Therefore, during inflammatory conditions of the gut, the mucosa becomes packed with immune cells in close proximity to the enterocytes. Mediators released from these cells have profound effects on epithelial functions.

The two main functions of the intestinal epithelium are, first, a transport function for nutrients, ions and water, and second, a barrier function to prevent unimpeded uptake of antigenic material and microbes from the lumen. Our work indicates that both these functions are altered by immune reactions in response to various stimuli. We have used several experimental systems to demonstrate these effects including in vivo studies in rodent models of intestinal hypersensitivity or inflammation, isolated segments of intact intestine studied in Ussing chambers and in vitro co-culture systems of immune cells with epithelial cell monolayers. Although our studies have examined the role of mast cells and $T$ cells as effector cells, it is obvious from the studies of others that activation of immune cells such as neutrophils, macro- phages and eosinophils also results in abnormalities of epithelial physiology.

\section{MAST CELLS AND EPITHELIAL FUNCTION}

Our early studies examined the effect of immune stimulation on intestinal transport. Rats sensitized to ovalbumin (with adjuvants, such as pertussis vaccine and alum, that stimulate immunoglobulin E production) studied 14 days later demonstrated reduced net absorption of sodium, potassium, chloride and water beginning within minutes of addition of antigen to the buffer perfusing the small intestine (1). These transport changes were associated with histamine release and were inhibited by mast cell stabilization (2).

Subsequent experiments examined the mechanisms of the response using isolated segments of intestine studied in Ussing chambers where an increase in the short-circuit current (Isc) indicates anion secretion (mainly chloride). Specific immune stimulation with ovalbumin antigen initiated a rapid (beginning within about 2 mins) secretory response that involved or increased Isc, increased net chloride secretion, and decreased net absorption of sodium and chloride (3). Mast cell mediators were implicated to result in en- 


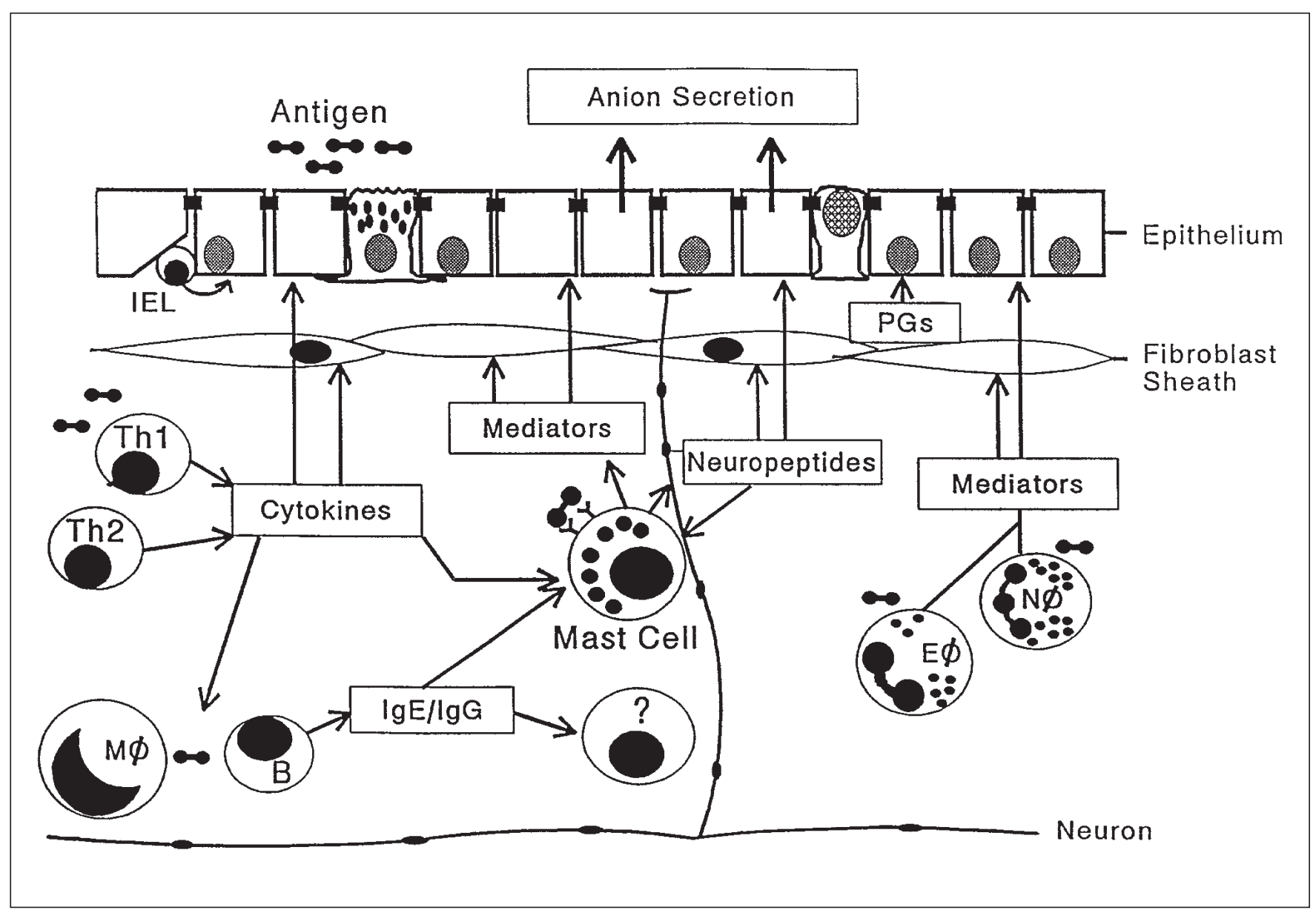

Figure 2) Revised schema for intestinal hypersensitivity reactions. Primary exposure to antigen results in $T$ cell activation, clonal expansion and cytokine release leading to B cell (B) stimulation of antibody production, specifically immunoglobulin (Ig) E and subclasses of IgG. These antibodies bind to mast cells and other effector cells. Secondary exposure to antigen causes release of mediators and cytokines that attract other inflammatory cells to the site and stimulate nerves. Anion secretion from epithelial cells is the final outcome of the direct and indirect (via prostaglandin [PG] production from fibroblasts) effects of various cytokines, neuropeptides and mediators. E $\Phi$ Eosinophils; IEL Intraepithelial lymphocytes; M $\Phi$ Macrophages; N $\Phi$ Neutrophils; Th Helper T cells

hanced production of cAMP in enterocytes immediately preceding the rise in intestinal Isc. These findings resulted in the schema shown in Figure 1 to explain the pathophysiology.

More direct evidence that specific immune stimulation of mast cells alters ion secretion came from studies of genetic mutant $\mathrm{W} / \mathrm{W}^{\mathrm{V}}$ mice. Mutations at the ckit locus result in an abnormal tyrosine kinase receptor for stem cell growth factor, which is necessary for the differentiation of functional mast cells from their precursors (4). These mice have less than $0.3 \%$ of the normal number of mast cells in skin and none at all in the gut (5). W/WV mice and +/+ congenic controls were sensitized in a similar manner to that described for rats. Studies of antigen-induced ion secretion in sensitized W/WV mice demonstrated a small Isc response to secondary antigen compared with the large response observed in intestine from congenic $+/+$ controls. However, mast cell reconstitution after adoptive transfer of congenic bone marrow cells restored the normal secretory response (6), demonstrating the important role of mast cells as effectors. In support of this hypothesis, antagonists of the mast cell me- diators, histamine and serotonin, produced inhibition in $+/+$ mice but none in $\mathrm{W} / \mathrm{W}^{\mathrm{V}}$.

\section{MAST CELL-NERVE INTERACTIVE UNITS REGULATE PHYSIOLOGY}

Anatomical studies have described associations between mast cells and nerves in the intestinal mucosa of nematodeinfected and normal rats and humans (7). We showed that the neurotoxin tetrodotoxin (TTX) could completely block increases in Isc caused by neurotransmitters released by transmural field stimulation (8). Pretreatment with TTX of intestinal tissues from sensitized $+/+$ mice reduced the response to antigen by more than $50 \%$. The fact that such inhibition was not evident in sensitized $\mathrm{W} / \mathrm{W}^{\mathrm{V}}$ mice provided further evidence that mast cells were interacting with nerves to stimulate ion secretion (6). In the presence of TTX, there was no difference in the response to antigen in mast celldeficient versus mast cell-containing intestine. Therefore, the effects of mast cells to stimulate ion secretion appear to be mediated through nerves. However, some residual effects 


\begin{tabular}{|c|c|}
\hline \multicolumn{2}{|l|}{ Stored } \\
\hline Amines & Histamine, serotonin \\
\hline Cytokines & TNF- $\alpha$ \\
\hline Enzymes & $\begin{array}{l}\text { Tryptase, chymotryptase, RMCP-I, } \\
\text { RMCP-II, carboxypeptidase }\end{array}$ \\
\hline Proteoglycans & Heparin, chondroitin-di- sulphate \\
\hline \multicolumn{2}{|l|}{ Rapidly formed } \\
\hline Lipid & $\begin{array}{l}\text { Prostaglandins, leukotrienes, } \\
\text { platelet-activating factor }\end{array}$ \\
\hline Reactive species & Nitric oxide, oxygen radicals \\
\hline \multicolumn{2}{|l|}{ Slowly formed } \\
\hline Cytokines & $\begin{array}{l}\text { IL-1, IL-3, IL-5, IL-6, IL-10, } \\
\text { TNF- } \alpha, \text { GM-CSF }\end{array}$ \\
\hline
\end{tabular}

GM-CSF Granulocyte-macrophage colony-stimulating factor; IL Interleukin; RMCP Rat mast cell protease; TNF- $\alpha$ Tumour necrosis factor-alpha

were still evident in mast cell-deficient mice, suggesting the participation of another effector cell or cells. In addition, stimulating nerves with field stimulation caused an increase in Isc, and that response was significantly less in mast cell-deficient mice. Therefore, some of the effects of release of neurotransmitters are mediated by mast cells. Thus, the schema for intestinal immunophysiological reactions has become more complicated, involving bidirectional signals between nerves and mast cells and separate effects of nonmast cells (Figure 2).

More direct studies of nerves and neural activity have demonstrated specific effects of inflammatory mediators on nerves. Histamine depolarizes neurons in the submucosal plexus and causes recurrent cyclical chloride secretion for prolonged periods via $\mathrm{H}_{2}$ receptors (9). Serotonin is another mediator of mast cells in some species and has been shown to induce ion secretion by acting on both $5-\mathrm{HT}_{2}$ and $5-\mathrm{HT}_{3}$ receptors on enteric nerves (10). It is a significant finding that the secretion induced by cholera toxin is inhibited by blocking these receptors (11), and recent studies in $\mathrm{W} / \mathrm{W}^{\mathrm{V}}$ mice suggest that a major source of serotonin released by cholera toxin may be the mast cell (12). In addition, there is evidence that the secretory effects of substance $\mathrm{P}$ in the intestine are mediated, at least in part, by mast cell activation (13). Intestinal responses to toxin A (from Clostridium difficile) associated with mast cell activation have been shown to be inhibited by substance P antagonists (14). We also reported that the Isc response to luminal antigen was reduced by approximately $50 \%$ by treating rats with capsaicin (which depletes substance $\mathrm{P}$ and other neuropeptides from afferents) (15). These latter studies support the theory that mast cells interact with substance P-containing nerves in an axon reflex.

Prostaglandins and leukotrienes are released from mast cells and other immunocytes and may also affect neurons (16-18). Sensitization alters the regulation of epithelial ion transport, particularly by leukotriene $\mathrm{B}_{4}$ interacting with enteric nerves (19). Other studies have demonstrated that epithelial permeability to macromolecular antigens and inert probe molecules is influenced by neural factors in that antigen uptake both in vivo and in vitro is inhibited by TTX $(20,21)$.

\section{ADDITIONAL CONSIDERATIONS RELATED TO MAST CELL ACTIVATION}

Mast cells release biologically active products in addition to the well-known mediators of hypersensitivity such as histamine, serotonin, proteases and leukotrienes. Among these is a vast array of multifunctional cytokines, and other active compounds such as platelet-activating factor and nitric oxide $(22,23)$ (Table 1$)$. Many of these compounds can stimulate ion secretion from intestinal preparations or epithelial monolayers (reviewed in 24).

One mast cell cytokine that has been demonstrated to have significant biological effects is tumour necrosis factoralpha (TNF- $\alpha$ ) because it is stored and released from mast cells with prolonged kinetics following activation (25). In fact, recruitment of neutrophils following cutaneous anaphylaxis was significantly impaired in $\mathrm{W} / \mathrm{W}^{\mathrm{V}}$ mice and in congenic controls by treatment with an anti-TNF- $\alpha$ antibody (26). TNF- $\alpha$, like interferon-gamma (IFN- $\gamma$ ), may be responsible for epithelial pathophysiology (27). Mast cells are also one source of $\mathrm{T}$ cell growth factor-beta that is important in repair of epithelial injury (28). Therefore, it is likely that mast cell activation contributes to a phenotypic change in epithelial cells during inflammation that may affect its transport function. These findings are relevant in a clinical setting, because mast cells have been implicated in the pathophysiology of diseases such as inflammatory bowel disease (IBD), celiac disease and food allergy, where debilitating diarrhea is a common symptom (reviewed in 29).

\section{NEUTROPHILS, EOSINOPHILS, MACROPHAGES}

Neutrophils, eosinophils and macrophages have all been implicated either directly or indirectly in affecting epithelial function. These phagocytes have some common properties in that when they are activated (by bacterial products or phagocytosis) they release potent chemicals such as reactive oxidant species (nitric oxide, hydrogen peroxide, Nchloramines), proteases and arachidonic acid metabolites (27). These cells also synthesize and react to various cytokines. The release of inflammatory mediators has beneficial effects in removing particulate antigens and infected or transformed cells; however, epithelial injury and/or dysfunction can occur as a result. Ongoing activation of these cells in chronic diseases may account for significant intestinal pathophysiology. There is some evidence that monocytes in Crohn's disease are primed by bacterial endotoxin (lipopolysaccharide [LPS]) for accentuated release of toxic oxygen metabolites (30).

LPS is a general activator of phagocytes and has provided a significant amount of information regarding the potential contribution of these cells in inflammatory reactions. LPS injection into animals leads to nitric oxide production by phago- 
cytic leukocytes that is required for the tumouricidal, tumouristatic and antimicrobial activity of macrophages (31).

Direct experimental studies have provided evidence for the effects of neutrophils on epithelial functions. Neutrophils stimulated to cross monolayers of the T84 human colonic cell line in response to gradients of chemotactic bacterial peptides, such as $\mathrm{f}$-met-leu-phe (32), cause a dramatic fall in transepithelial resistance and increased fluxes of inert probes as well as protein antigens. The translocation is facilitated by the expression of the beta-2 integrin (CD11b/CD18) on the surface of the neutrophil, binding with the appropriate ligand on the enterocytes (33). Treatment with IFN- $\gamma$ elicits enhanced neutrophil transepithelial migration (34). Activated neutrophils in the intestinal lumen (as in the case of crypt abscesses) can evoke chloride secretion from the epithelium by the release of a molecule originally termed neutrophil-derived cAMP (34).

Eosinophils isolated from human blood evoke chloride secretion from T84 monolayers by the release of cAMP (35). The effects of other eosinophil products such as major basic protein and eosinophil-derived neurotoxin have not been tested in the gut but have deleterious effects on the epithelial lining of the airways. In addition, release of eosinophil cationic protein has been demonstrated in response to allergen in food allergic individuals (36) and in response to gliadin in patients with celiac disease (37). Eosinophils have been shown to contribute to the inflammatory response in other systems (38) and demonstrate an altered appearance in inflamed intestine in Crohn's disease (39).

\section{T CELLS}

The gastrointestinal tract is the largest immune organ in the body and represents a major $\mathrm{T}$ cell compartment where the cells are located in the lamina propria or epithelium (intraepithelial lymphocytes). $T$ cells are further classified by the presence of surface markers into helper $\left(T_{h}\right)$ or suppressor/cytotoxic $\left(T_{s / c}\right)$. Studies in the early 1970s implicated $\mathrm{T}$ cells in causing villus atrophy/crypt hyperplasia. Subsequent studies examining transfer of $\mathrm{T}$ cells from normal donors to irradiated or immunocompromised recipients helped confirm that $\mathrm{T}$ cells influence intestinal morphology by affecting epithelial proliferation (reviewed in 40). By using human fetal intestinal explants, it was shown that in situspecific $T$ cell stimulation led to a crypt cell hyperplasia that preceded villus atrophy (41). We confirmed that this sequence of events also occurred when T cells were stimulated during intestinal inflammatory reactions by nematode parasitic infection $(42,43)$. It is clear that $T$ cell activation can result in increased epithelial proliferation rates in the crypt mediated by the release of cytokines from $T_{h}$ cells.

The impact of $\mathrm{T}$ cells on the two main roles of the intestinal epithelium has not been extensively studied. To address this question, we have established an in vitro co-culture model of inflammation consisting of confluent T84 epithelial cell monolayers and peripheral blood mononuclear cells (PBM) from human volunteers, in which the T cell compo- nent is stimulated in the T cell receptor. We have presented preliminary findings showing that such activation in mixed lymphocyte/monocyte populations can alter epithelial physiology (44). Monolayers that are exposed to activated T cells demonstrate reduced ion secretory capacity to several known secretagogues and increased permeability. Transepithelial resistance is also decreased across monolayers exposed to nonactivated PBM as well as to PBM in which T cells are activated. In support of these findings, co-culture of T84 monolayers with lamina propria lymphocytes isolated from intestine surgically removed from ulcerative colitis patients increased epithelial permeability (45). These in vitro approaches provide the opportunity to accumulate data on the mechanism whereby immunocytes affect various aspects of epithelial function.

\section{PROSTAGLANDINS AND IMMUNE CELL ACTIVATION}

Other findings that have been of great importance in developing our understanding of immunophysiology are those that describe the role of prostaglandins in mediating the effects of inflammatory mediators (46). Since epithelial cells generate small amounts of prostaglandins relative to cells of the lamina propria, and since activation of isolated immune/inflammatory cells initiates the metabolism of arachidonic acid, the participation of accessory cells has been suggested. Elegant co-culture studies of T84 epithelial monolayers with fibroblasts demonstrated that prostaglandin production by fibroblasts is responsible for a large component of the secretory response to inflammatory mediators originating from immune cells (47). These studies demonstrated that fibroblasts generate prostaglandin $\mathrm{E}_{2}$ and prostacyclin, which act directly or indirectly via enteric nerves to cause secretion in rat colon (48).

\section{SUMMARY AND CONCLUSIONS}

As a result of our studies and those of others, there is no longer a controversy regarding immune regulation of epithelial functions. In addition, in many cases the effects of immune activation are amplified by nerves. Thus, it appears that an effective system has evolved to detect and react to antigenic challenge of the gut via a neural reflex mechanism. The information accumulated over the recent past has resulted in a modification of our original schema of hypersensitivity reactions (Figure 2 ). The benefit of this system to the organism in acute situations must be weighed against its deleterious effects when continuous activation results in ongoing release of mediators leading to chronic inflammatory diseases. Our knowledge is now probing the mechanisms that turn off such responses. However, it is clear that the concepts of immunophysiology are essential for deciphering the pathophysiology of IBD and identifying targets for therapeutic agents.

\section{REFERENCES}

1. Perdue MH, Chung M, Gall DG. The effect of intestinal anaphylaxis on gut function in the rat. Gastroenterology 1984;86:391-7.

2. Perdue MH, Gall DG. Transport abnormalities during intestinal 
anaphylaxis in the rat. Effect of anti-allergic agents. J Allergy Clin Immunol 1985;76:498-503.

3. Perdue MH, Gall DG. Intestinal anaphylaxis in the rat: jejunal response to in vitro antigen exposure. Am J Physiol 1986;250:G427-31.

4. Galli SJ, Kitamura Y. Genetically mast cell-deficient $\mathrm{W} / \mathrm{W}^{\mathrm{V}}$ and $\mathrm{SI} / \mathrm{SI}^{\mathrm{d}}$ mice. Their value for the analysis of the roles of mast cells in biologic responses in vivo. Am J Pathol 1987;127:191-8.

5. Wershil BK, Galli SJ. Gastrointestinal mast cells. New approaches for analyzing their function in vivo. Gastroenterol Clin North Am 1991;20:613-27.

6. Perdue MH, Masson S, Wershil BK, Galli SJ. Role of mast cells in ion transport abnormalities associated with intestinal anaphylaxis. Correction of the diminished secretory response in genetically mast cell-deficient $\mathrm{W} / \mathrm{W}^{\mathrm{v}}$ mice by bone marrow transplantation. J Clin Invest 1991;87:687-93.

7. Stead RH, Perdue MH, Blennerhassett MG, Kakuta Y, Sestini P, Bienenstock J. The innervation of mast cells. In: Freir S, ed. Neuroendocrine-Immune Network. Boca Raton: CRC Press, Inc, 1990:19-37.

8. Perdue MH, Davison JS. Response of jejunal mucosa to electrical transmural stimulation and two neurotoxins. Am J Physiol 1986;251:G642-8.

9. Cooke HJ, Wang Y, Rogers R. Coordination of $\mathrm{Cl}^{-}$secretion and concentration by a histamine $\mathrm{H} 2$-receptor agonist in guinea pig distal colon. Am J Physiol 1993;265:G973-8.

10. Frieling T, Cooke HJ, Wood JD. Serotonin receptors on submucous neurons in guinea pig colon. Am J Physiol 1991;261:G1017-23.

11. Sjöqvist A, Cassuto J, Jodal M, Lundgren O. Actions of serotonin antagonists on cholera-toxin-induced intestinal fluid secretion. Acta Physiol Scand 1992;145:229-37.

12. Wang L, Savedia S, Benjamin M, Perdue MH. Advances in Mucosal Immunology. New York: Plenum Press, 1995:287-92.

13. Wang L, Stanisz AM, Wershil BK, Galli SJ, Perdue MH. Substance $\mathrm{P}$ induces ion secretion in mouse small intestine through effects on both enteric nerves and mast cells. Am J Physiol 1995;269:G85-92.

14. Pothoulakis C, Castagliuolo I, LaMont JT, et al. CP 96,345, a substance $\mathrm{P}$ antagonist, inhibits rat intestinal responses to Clostridium difficile toxin A but not cholera toxin. Proc Natl Acad Sci USA 1994;91:947-51.

15. Crowe SE, Sestini P, Perdue MH. Allergic reactions of rat jejunal mucosa. Ion transport responses to luminal antigen and inflammatory mediators. Gastroenterology 1990;99:74-82.

16. Levine JD, Lam D, Taiwo YO, Donatoni P, Goetzl EJ. Hyperalgesic properties of 15-lipoxygenase products of arachidonic acid. Proc Natl Acad Sci USA 1986;83:5331-4.

17. Diener M, Bridges RJ, Knoblock SF, Rummel W. Neuronally mediated and direct effects of prostaglandins on ion transport in rat colon descendens. Naunyn Schmiedebergs Arch Pharmacol 1989;337:74-8

18. Hammerbeck DM, Brown DR. Neurally mediated actions of leukotrienes on ion transport in guinea pig distal colon. J Pharmacol Exp Ther 1993;264:384-90.

19. Javed NH, Barrett KE, Wang YZ, Bidinger J, Cooke HJ. Enhanced tissue responsiveness in colonic ion transport of cow's milk-sensitized guinea pigs. Agents Actions 1994;41:25-31.

20. Crowe SE, Soda K, Stanisz AM, Perdue MH. intestinal permeability in allergic rats: nerve involvement in antigen-induced changes. Am J Physiol 1993;264:G617-23.

21. Kimm MH, Curtis GH, Hardin JA, Gall DG. Transport of bovine serum albumin across rat jejunum: the role of the enteric nervous system. Am J Physiol 1994;266:G186-93.

22. Galli SJ, Gordon JR, Wershill BK. Cytokine production by mast cells and basophils. Curr Opin Immunol 1991;3:865-73.

23. Serafin WE, Austen KF. Mediators of immediate hypersensitivity reactions. N Engl J Med 1987;317:30-4.

24. Powell DW. Epithelial secretory responses to inflammation. Platelet activating factor and reactive oxygen metabolites. Ann NY Acad Sci 1992;664:232-47.

25. Payan DG. Neuropeptides and inflammation: the role of substance P. Annu Rev Med 1989;40:341-52.

26. Wershil BK, Wang Z-K, Gordon JR, Galli SJ. Recruitment of neutrophils during IgE-dependent cutaneous late phase responses in the mouse is mast cell dependent: partial inhibition of the reaction with antiserum against tumor necrosis factor- $\alpha$. J Clin Invest 1991;87:446-53

27. McKay DM, Perdue MH. Intestinal epithelial function: the case for immunophysiological regulation. Cells and mediators. (Part 1 of 2). Dig Dis Sci 1993;38:1377-87.

28. Ciacci C, Lind SE, Podolsky DK. Transforming growth factor-beta regulation of migration in wounded rat intestinal epithelial monolayers. Gastroenterology 1993;105:93-101.

29. Crowe SE, Perdue MH. Gastrointestinal food hypersensitivity: basic mechanisms of pathophysiology. Gastroenterology 1992;103:1075-95.

30. Baldassano RN, Schreiber S, Johnston RB, Fu RDJ, Muraki T, MacDermott RP. Crohn's disease monocytes are primed for accentuated release of toxic oxygen metabolites. Gastroenterology 1993;105:60-6.

31. Grisham MB, Yamada T. Neutrophils, nitrogen oxides, and inflammatory bowel disease. Ann NY Acad Sci 1992;664:103-15.

32. Nash S, Parkos C, Nusrat A, Delp C, Madara JL. In vitro model of intestinal crypt abscess. J Clin Invest 1991;87:1474-7.

33. Parkos CA, Delp C, Arnaout MA, Madara JL. Neutrophil migration across a cultured intestinal epithelium. J Clin Invest 1991;88:1605-12.

34. Colgan SP, Parkos CA, Delp C, Arnaout MA, Madara JL. Neutrophil migration across cultured intestinal epithelial monolayers is modulated by epithelial exposure to IFN-gamma in a highly polarized fashion. J Cell Biol 1993;120:785-98.

35. Resnick MB, Colgan SP, Patapoff TW, et al. Activated eosinophils evoke chloride secretion in model intestinal epithelia primarily via regulated release of 5'-AMP. J Immunol 1993;151:5716-23.

36. Knutson TW, Bengtsson U, Dannaeus A, et al. Intestinal reactivity in allergic and nonallergic patients: an approach to determine the complexity of the mucosal reaction. J Allergy Clin Immunol 1993;91:553-9.

37. Lavö B, Knutson L, Lööf L, Odlind B, Venge P, Hällgren R. Challenge with gliadin induces eosinophil and mast cell activation in the jejunum of patients with celiac disease. Am J Med 1989;87:655-60.

38. Denburg JA, Otsuka H, Ohnisi M, Ruhno J, Bienenstock J, Dolovich J. Contribution of basophil/mast cell and eosinophil growth and differentiation to the allergic tissue inflammatory response. Int Arch Allergy Appl Immunol 1987;82:321-6.

39. Dvorak AM, Monohan RA, Osage JE, Dickersin GR. Crohn's disease: transmission electron microscopic studies. II. Immunologic inflammatory response. Alterations of mast cells, basophils, eosinophils, and the microvasculature. Hum Pathol 1980;11:606-19.

40. MacDonald TT, Path M, Spencer J. Cell-mediated immune injury in the intestine. Gastroenterol Clin North Am 1992;21:367-86.

41. Mac Donald TT, Spencer J. Evidence that activated mucosal T cells play a role in the pathogenesis of enteropathy in human small intestine. J Exp Med 1988;167:1341-9.

42. Perdue MH, Ramage JK, Burget D, Marshall JS, Masson S. Intestinal mucosal injury is associated with mast cell activation and leukotriene generation during Nippostrongylus-induced inflammation in the rat. Dig Dis Sci 1989;34:724-31.

43. D'Inca R, Ernst P, Hunt RH, Perdue MH. Role of T lymphocytes in intestinal mucosal injury. Inflammatory changes in athymic nude rats. Dig Dis Sci 1992;37:33-9.

44. McKay DM, Croitoru K, Perdue MH. T cell-monocyte interactions regulate epithelial physiology in a co-culture model of inflammation. Am J Physiol 1996;270:C418-28.

45. Roche JK, Planchon S, Lai J, Fiocchi C. Effect of ulcerative colitis immune mucosal cells upon epithelial barrier function. Gastroenterology 1993;104:A771. (Abst)

46. Powell DW. Immunophysiology of intestinal electrolyte transport. In: Schultz SG, ed. Handbook of Physiology. The Gastrointestinal System IV. Rockville: The American Physiologic Society, 1991:591-641.

47. Berschneider HM, Powell DW. Fibroblasts modulate intestinal secretory response to inflammatory mediators. J Clin Invest 1992;89:484-9.

48. Bern MJ, Sturbaum CW, Karayalcin SS, Berschneider HM, Wachsman JT, Powell DW. Immune system control of rat and rabbit colonic electrolyte transport. Role of prostaglandins and enteric nervous system. J Clin Invest 1989;83:1810-20. 


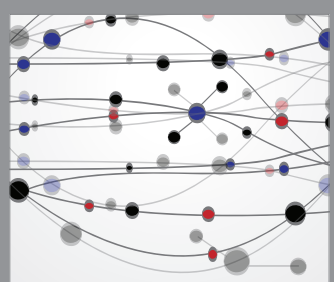

The Scientific World Journal
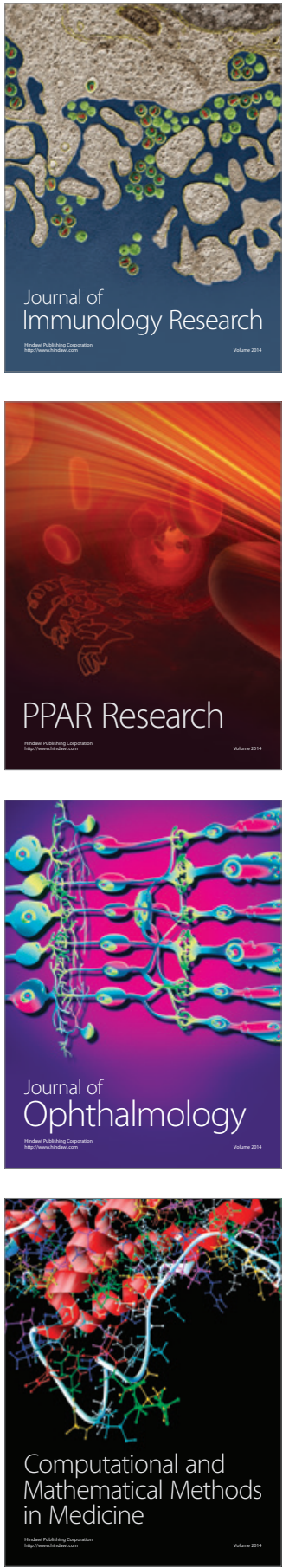

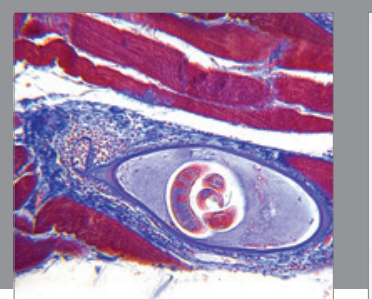

Gastroenterology Research and Practice

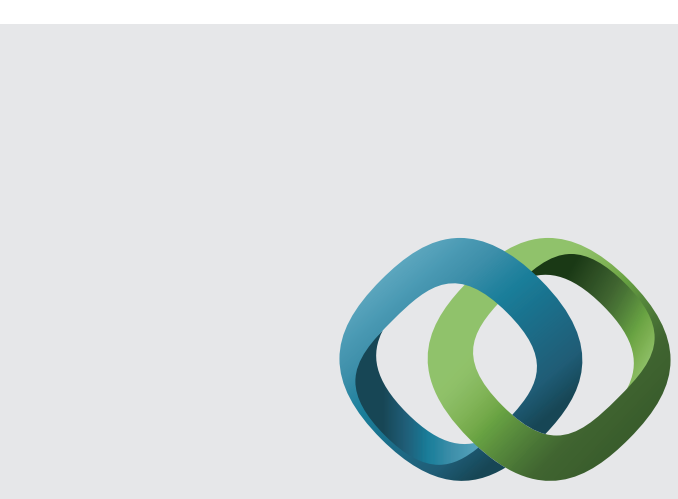

\section{Hindawi}

Submit your manuscripts at

http://www.hindawi.com
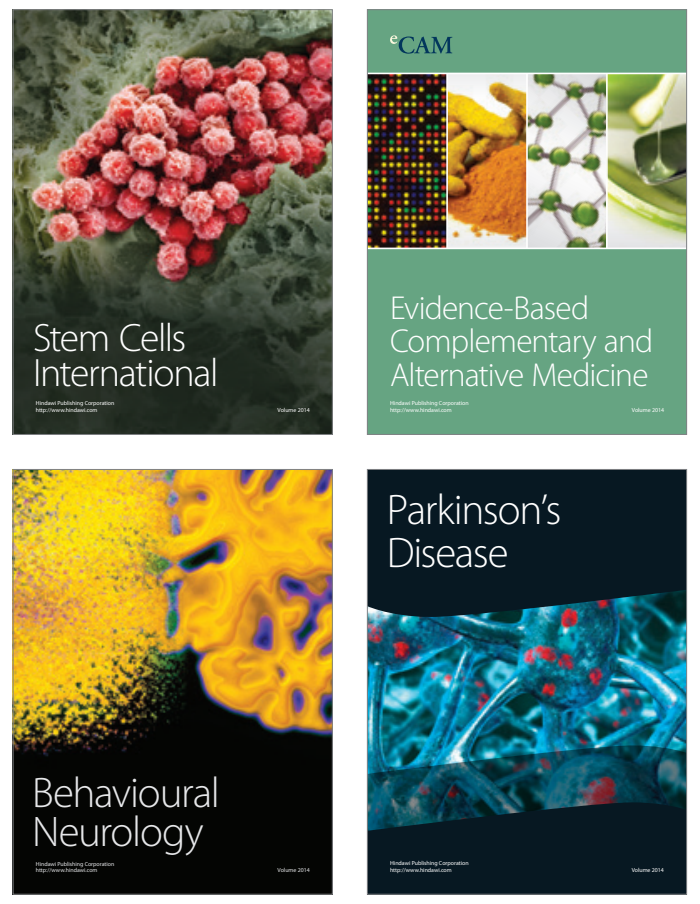
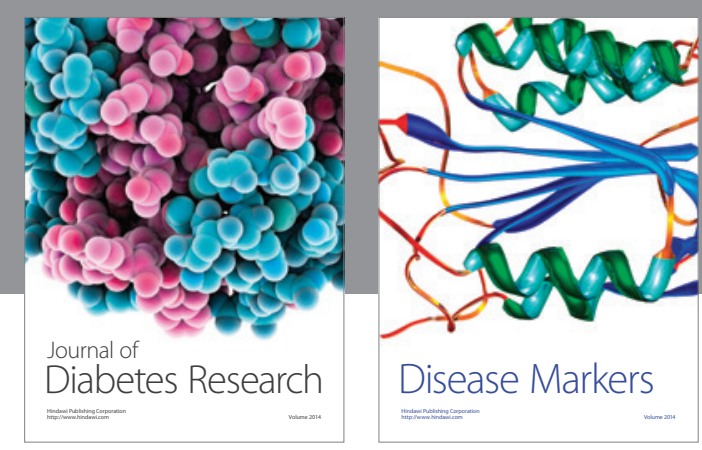

Disease Markers
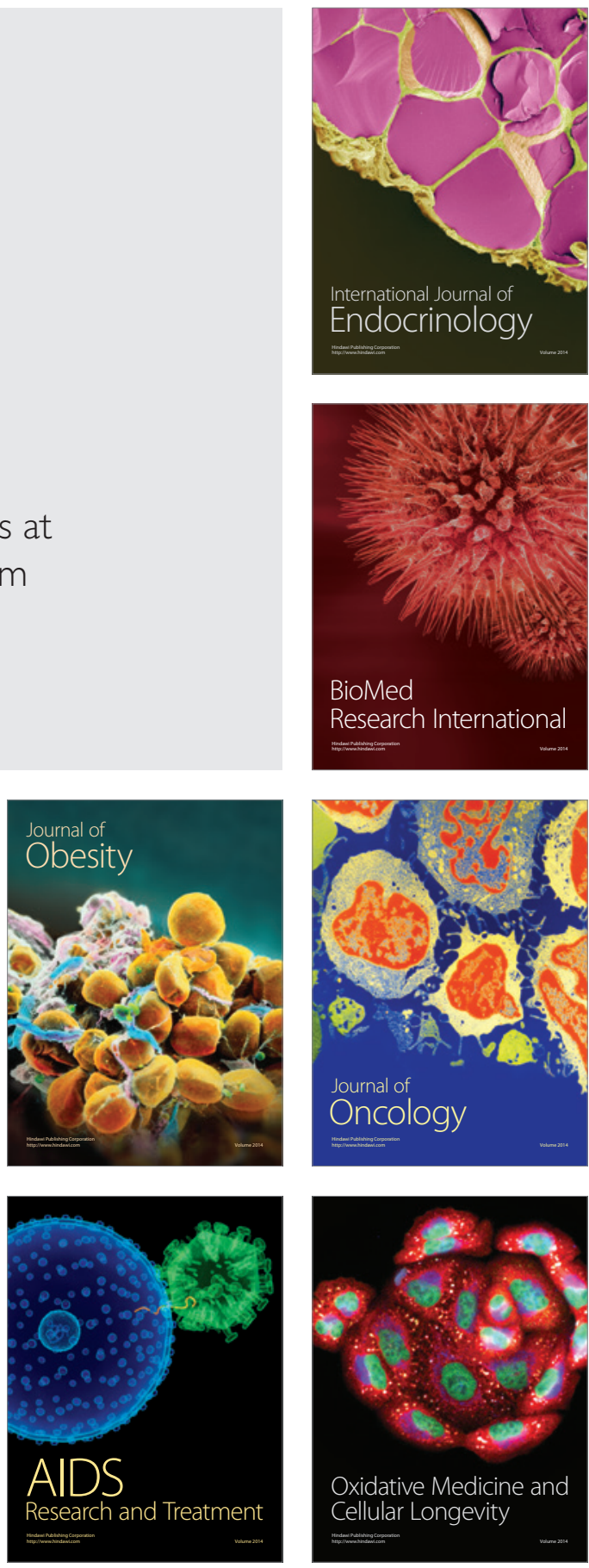